\title{
Études/Inuit/Studies
}

\section{Biographical notes and bibliography of Michael E. Krauss}

Volume 29, numéro 1-2, 2005

Préserver la langue et les savoirs

Preserving language and knowledge

URI : https://id.erudit.org/iderudit/013931ar

DOI : https://doi.org/10.7202/013931ar

Aller au sommaire du numéro

Éditeur(s)

Association Inuksiutiit Katimajiit Inc.

Centre interuniversitaire d'études et de recherches autochtones (CIÉRA)

ISSN

0701-1008 (imprimé)

1708-5268 (numérique)

Découvrir la revue

Citer ce document

(2005). Biographical notes and bibliography of Michael E. Krauss. Études/Inuit/Studies, 29(1-2), 35-46. https://doi.org/10.7202/013931ar d'utilisation que vous pouvez consulter en ligne.

https://apropos.erudit.org/fr/usagers/politique-dutilisation/ 


\section{Biographical notes and bibliography of Michael E. Krauss}

\section{Personal:}

Born 15 August, 1934.

Married in 1962 to Jane Lowell (1934-2003), six children.

\section{Higher education:}

Massachusetts Institute of Technology 1969-70 (linguistic theory).

University of Iceland 1958-60, Baccalaureatus philologiae Islandicae 1960.

Harvard University 1957-58, Ph.D. 1959 (linguistics and Celtic, dissertation "Studies in Irish Gaelic Phonology and Orthography").

Dublin Institute for Advanced Studies 1956-57, Research Fellow.

University of Paris 1955-56, Certificat d'études supérieures 1956.

Columbia University 1954-55, M.A. 1955 (linguistics and Romance philology).

Western Reserve University 1953-54, B.A. 1954 (Romance languages).

University of Chicago 1950-53, B.A. 1953 (liberal arts).

\section{Professional positions and experience:}

-University of Alaska, 1960 to present:

Carnegie Visiting (Assistant) Professor of Linguistics, 1960-1962;

Associate Professor of Linguistics 1962-68;

Professor of Linguistics, 1968-2000;

Professor Emeritus, 2000-;

Head, Department of Linguistics and Foreign Languages, 1961-64;

Head, Alaska Native Language Program, 1972-2000;

Director, Alaska Native Language Center, 1972-2000. 
-Massachusetts Institute of Technology, 1969-70: Visiting Professor of Linguistics (on sabbatical leave from University of Alaska).

-National Science Foundation Linguistics panel member, 1981-84.

-International Journal of American Linguistics, Editorial Board member, 1982-2003.

-Arctic Anthropology, Editorial Board member, 1989-.

-President, Society for the Study of the Indigenous Languages of the Americas, 1991.

-Chairman, Committee on Endangered Languages, Linguistic Society of America, 1991-93.

-Member, UNESCO Committee on Language Endangerment, 1992-93.

\section{Honours, scholarships, fellowships and grants:}

State of Alaska, Governor's Award for Distinguished Service to the Humanities, 2002.

Alaska Humanities Forum, Distinguished Humanist of the Year 1981.

National Endowment for the Humanities grants, principal investigator: research for and preparation of major dictionaries of eleven Alaska Native Languages, 1978-1983; for development of Yupik Eskimo Teaching Grammar, 1969; Alaska Native Writers Project, 1974-76; Alaska Native Language Center Library Catalog 1976-1977, 198182.

National Science Foundation research grants, principal investigator: basic research on Athabaskan and Eyak linguistics in Alaska 1961-68; St. Lawrence Island Yupik 197071; Alaskan Dictionary Project 1978-81 and 1982-84.

Fulbright Travel and Study Grant, Iceland and the Faroe Islands, 1958-60. Halldor Kiljan Laxness Fellowship, Scandinavian-American Foundation, for study in Iceland, 1958-59.

George C. Shattuck Fellowship, Harvard University, 1957-58.

Research Fellowship, Dublin Institute for Advanced Studies, 1956-57 (fieldwork on Inis Meadhóin, Co. Galway).

Boursier du Gouvernement français, 1955-56.

\section{Fields of interest:}

Minority/Endangered/Northern languages; Language Policies and Political Context; Documentation and Preservation of Languages; Historical Records and Resources. 


\section{Specific language areas of interest:}

Celtic (especially Irish Gaelic); Scandinavian (especially Icelandic and Faroese); Eyak; Athabaskan (especially Tanana, Han, and all other Alaskan; Comparative Athabaskan; Tsetsaut, Beaver, Chilcotin, Kwalhioqua-Tlatskanai,Plains Apache); Eskimo-Aleut (especially Central Siberian Yupik, Naukan, Sirenikski; Kurile Aleut)

\section{Research and related activities:}

Fieldwork survey of Alaskan Athabaskan languages 1961-63 and occasionally since; fieldwork on and analysis of Eyak, 1963-; much unpublished material and study on Athabaskan, comparative Athabaskan, and Eyak; preparation of the Eyak Texts and Eyak Dictionary occupied most of research time 1963-69. Fieldwork on St. Lawrence Island Yupik 1971-2 and occasionally since; fieldwork on Naukan Yupik 1985, 1996. Research on and teaching of Eskimo at the University of Alaska, 1961-1963, occasionally since; program being continued and further developed by E.I. Reed, S.A. Jacobson, and others.

Since 1970 involvement in statewide programs in support of all Alaska Native Languages, administrative, organizational, and political work, resulting in bilingual education legislation, creation of Alaska Native Language Center, development of orthographies and beginning literatures; literacy workshops throughout Alaska for Tlingit, Haida, Athabaskans, Eskimos, Aleuts; training of Alaska Natives for professional level work with own languages; coordination with work in DenmarkGreenland, Canada, and USSR/Russia.

Assembling and archiving, and bibliographical work on comprehensive collection of all materials, published and unpublished, in or on Alaska Native languages.

Coordinator of exchange of Eskimo-Aleut language materials with U.S.S.R. (ACLSANSSSR), academic and diplomatic work for reestablishing communication between Soviet and Alaskan Eskimos.

Editor, Alaska Native Language Center Research Papers, seven volumes published 1979-1985.

Principal Investigator and general editor, major dictionaries of Alaskan languages (Central Yup'ik, Alutiiq, Siberian Yupik, Aleut, Inupiaq, Eyak, Tlingit, Haida, Koyukon, Ahtna, Tanaina), in progress.

Founding Chair, Linguistic Society of America Committee on Endangered Languages 1991-1994. 


\section{Publications, books and papers (since 1964):}

KRAUSS, Michael E.

1964 Proto-Athabaskan-Eyak and the Problem of Na-Dene I: Phonology, International Journal of American Linguistics, 30: 118-131.

1965 Proto-Athabaskan-Eyak and the Problem of Na-Dene II: Morphology, International Journal of American Linguistics, 31: 18-28.

1965 Eyak: a Preliminary Report, Canadian Journal of Linguistics, 10: 167-186.

1968 Noun-classification Systems in Athabaskan, Eyak, Tlingit, and Haida Verbs, International Journal of American Linguistics, 34: 193-203.

1969 On the Classifiers in the Athabaskan, Eyak, and Tlingit Verb, Baltimore, Waverly Press, Indiana University Publications in Anthropology and Linguistics, Memoir 24.

1970 Eyak Texts, Boston, Massachusetts Institute of Technology, typescript texts, translations, notes, 912 pages.

1970 Eyak Dictionary, Boston, Massachusetts Institute of Technology, typescript, ca. 4,000 pages.

1973 Eskimo-Aleut, in Thomas Sebeok (ed.), Linguistics in North America, The Hague, Mouton, Current Trends in Linguistics, 10(2): 796-902.

1973 Na-Dene, in Thomas Sebeok (ed.), Linguistics in North America, The Hague, Mouton, Current Trends in Linguistics, 10(2): 903-908.

1974 E. S. Rubtsova, International Journal of American Linguistics, 40: 44-46.

1974 St. Lawrence Island and Siberian Eskimo Literature, Fairbanks, Alaska Native Language Center, typescript report on all books and materials printed in the U.S.S.R. for Soviet Eskimos (1932-1965) and in Alaska for St. Lawrence Islanders, 44 pages.

1974 Minto-Nenana Noun Dictionary, preliminary version, Fairbanks, Alaska Native Language Center, 56 pages.

1974 Native Peoples and Languages of Alaska, Fairbanks, Alaska Native Language Center, full color map, 3' x 4'.

1975 St. Lawrence Island Eskimo Phonology and Orthography, Linguistics, 152: 40-72 (Analysis of the sounds of the language and report on development of writing systems for it in Alaska 1910-72 and the U.S.S.R. 1932-56). 
1975 Proto-Athabaskan Fricatives and the First Person Singular, typescript, 60 pages.

1975 Proto-Athabaskan-Eyak Kinship Terms, typescript, 40 pages.

1975 Chilcotin Phonology: A descriptive and historical report with recommendations for an orthography, typescript, 55 pages.

with E. I. REED, O. MIYAOKA, S. JACOBSON and P. AFCAN

1977 Yup'ik Eskimo Grammar, Fairbanks, Alaska Native Language Center and Yup'ik Language Workshop, 329 pages.

1979 The Eskimo Languages in Alaska, Yesterday and Today, in Bjarne Basse and Kirsten Jensen (eds), Eskimo Languages: Their Present-day Conditions, Aarhus, Arkona: 37-50.

1979 Eskimo sprogene i Alaska i fortid og nutid, in Bjarne Basse and Kirsten Jensen (eds), Eskimosprogenes vilkår i dag, Aarhus, Arkona: 37-50.

1979 Eskimo-Aleut and Na-Dene, in Lyle Cambell and Marianne Mithun (eds), The Languages of Native America: Historical and Comparative Assessments, Austin and London, University of Texas Press: 803-901.

1979 Athabaskan Tone, typescript, 63 pages.

1980 Alaska Native Languages, a Bibliographical Catalogue, Part I: Indian Languages, Fairbanks, Alaska Native Language Center, ANLC Research Paper, 3, 455 pages.

1980 Alaska Native Languages: Past, Present, and Future, Fairbanks, Alaska Native Language Center, ANLC Research Paper, 4, 110 pages.

1980 On the History and Use of Comparative Athabaskan Linguistics, typescript, 63 pages.

with J. A. LEER

1981 Athabaskan, Eyak, and Tlingit Sonorants, Fairbanks, Alaska Native Language Center, ANLC Research Paper, 5, 210 pages.

with Vera OOVI KANESHIRO

1981 St. Lawrence Island Yupik Short and Long Vowels, Fairbanks, Alaska Native Language Center, 27 pages.

with V. K. GOLLA

1981 Northern Athapaskan Languages in June Helm (ed.), Handbook of North American Indians, Vol. 6, Subarctic, Washington, D.C., Smithsonian Institution: 67-85. 
1981 Alaska Native Languages: Past, Present, and Future, paper presented at USUSSR Symposium, Leningrad, May 1979.

1981 Yazyki korennogo naseleniya Alyaski: Proshloe, nastoyashchee i budushchee, in V. P. Alekseev (ed.), Traditsionnye Kul'tury Severnoy Sibiri i Severnoy Ameriki , Moscow, Izdatel'stvo "Nauka": 149-181.

1982 Native Peoples and Languages of Alaska, Fairbanks, Alaska Native Language Center, full color map, 3' x 4', second edition, revised.

1982 Proto-Athabaskan *k in Chipewyan, 1742-1800: Philological evidence, International Journal of American Linguistics, 48: 73-82.

1982 In Honor of Eyak: The Art of Anna Nelson Harry, edited with translations and critical commentary, Fairbanks, Alaska Native Language Center, 165 pages.

1982 For G. A. Menovshchikov, Études/Inuit/Studies, 6(1): 127-129.

1983 Slavey Jargon: the diffusion of French in Northern Athabaskan, typescript, 20 pages.

1983 Introduction (and phonology), in R. Ridley (ed.), Eagle Han Huch'inn Hòdök, Fairbanks, Alaska Native Language Center: 6-9.

as editor

1985 Yupik Eskimo Prosodic Systems: Descriptive and Comparative Studies, Fairbanks, Alaska Native Language Center, ANLC Research Paper, 7, 216 pages.

1985 Introduction, in Michael E. Krauss (ed.), Yupik Eskimo Prosodic Systems: Descriptive and Comparative Studies, Fairbanks, Alaska Native Language Center, ANLC Research Paper, 7: 1-6.

1985 A History of the Study of Yupik Prosody, in Michael E. Krauss (ed.), Yupik Eskimo Prosodic Systems: Descriptive and Comparative Studies, Fairbanks, Alaska Native Language Center, ANLC Research Paper, 7: 7-23.

1985 Supplementary Notes on Central Siberian Yupik Prosody, in Michael E. Krauss (ed.), Yupik Eskimo Prosodic Systems: Descriptive and Comparative Studies, Fairbanks, Alaska Native Language Center, ANLC Research Paper, 7: 47-50.

1985 Sirenikski and Naukanski, in Michael E. Krauss (ed.), Yupik Eskimo Prosodic Systems: Descriptive and Comparative Studies, Fairbanks, Alaska Native Language Center, ANLC Research Paper, 7: 174-190. 
1985 Bibliography, in Michael E. Krauss (ed.),Yupik Eskimo Prosodic Systems: Descriptive and Comparative Studies, Fairbanks, Alaska Native Language Center, ANLC Research Paper, 7: 211-216.

1985 Russian Ikra 'Caviar; Calf of Leg' and Similar Pairs in Athabaskan-Eyak, International Journal of American Linguistics, 51: 485-486.

1985 Phonograph Cylinder Recordings of 1909-1910 by Jochelson and the Aleut Text Corpus, in Executive Committee of the International Symposium (ed.), Proceedings of the International Symposium on B. Pilsudski's Phonographic Records and the Ainu Culture, Sapporo, Hokkaido University: 203-213.

1986 A Survey of Major Alaskan Language Types, in W. P. Lehmann (ed.), Language Typology 1985: Papers from the Linguistic Typology Symposium, Moscow, 9-13 Dec. 1985, Amsterdam, John Benjamins: 169185.

1986 Edward Sapir and Athabaskan Linguistics, paper presented at the Sapir Centennial Conference, Ottawa.

1986 Edward Sapir and Athabaskan Linguistics, in W. Cowan, M. Foster and K. Koerner (eds), New perspectives in language, culture, and personality, Amsterdam, John Benjamins: 147-190.

1986 The Position of Naukan in Yupik, Fairbanks, Alaska Native Language Center, typescript, 20 pages.

1987 Typology and Change in Alaskan Languages, in W. P. Lehmann (ed.), Language Typology 1987. Systemic Balance in Language. Papers from the U.S.-U.S.S.R. Linguistic Typology Symposium, Berkeley, 1-3 Dec. 1987, Amsterdam, John Benjamins: 147-156.

1987 The Name Athabaskan, in Faces, Voices and Dreams, Sitka, Division of Alaska State Museums: 105-109.

1988 Many Tongues-Ancient Tales, in W. F. Fitzhugh and A. Crowell (eds), Crossroads of Continents: Cultures of Siberia and Alaska, Washington D.C., Smithsonian Institute: 144-150.

1989 Alaska-Chukotka Language Connections, paper presented at the CircumPacific Prehistory Conference, Seattle, typescript, 14 pages.

1989 Editor of "Ataasiighutelleq Kaangqugenka Amarankuk Sovietski-nkuk Ataasiighutellghak Yugitnum Ukumllu Tespamanillu Laalighqwaaghutelleghqiitneng Bering-em Aghviqani," by Linda Womkon 
Badten and Svetlana Taghyuq (published without permission or attribution as Une Entente américano-soviétique/A Soviet-American Agreement, Études/Inuit/Studies, 13(2): 117-131).

1990 History of Russian-Soviet Eskimo-Aleut Linguistics and Foreign Relations", paper presented at the 7th Inuit Studies Conference, Fairbanks, typescript, 4 pages.

1990 Alaska Native Languages in Russian America, in B. S. Smith and J. Barnett (eds), Russian America: The Forgotten Frontier, Tacoma, WA, The Washington State Historical Society: 205-214.

1990 Kwalhioqua and Clatskanie, in Wayne Shuttle (ed.), Handbook of North American Indians, vol. 7, Northwest Coast, Washington, D.C., Smithsonian Institution: 530-532.

1990 Foreword, in Knut Bergsland and Moses Dirks (eds), Unangam Ungiikangin Kayux Tunusangin/Unangam Uniikangis ama Tunuzangis/Aleut Tales and Narratives, Fairbanks, Alaska Native Language Center: xii-xv.

1992 Statement in Hearing before the Select Subcommittee on Indian Affairs, U.S. Senate... on S.1595, October 19, 1991, Washington, D.C., USGPO: 17$23,71-72$.

1992 The World's Languages in Crisis, Language, 68(1): 4-10.

1992 A Loss for Words, Earthwatch, 11(3): 10-12.

1992 Statement in Hearing before the Select Subcommittee on Indian Affairs, U.S. Senate... on S.2044, June 18, 1992, Washington, D.C., USGPO: 18-22, and Report in Calendar No. 569, July 27, 1992.

1992 Ode' Setl'oghwnh Da'/Long After I Am Gone/Stories by Teddy Charlie, Fairbanks, Alaska Native Language Center, 26 pages (Original transcription and Foreword by Michael Krauss).

1992 General Assembly Resolution, August 14, 1992, Permanent International Committee of Linguists, UNESCO, New Language Planning Newsletter, $8(1): 3$.

1992 Status of Eskimo Languages in World Perspective, in Nelson H. H. Graburn (ed.), Proceedings of the Conference "Language and Educational Policy in the North", Berkeley, University of California, Berkeley: 15-27.

1993 The Language Extinction Catastrophe Just Ahead: Should Linguists Care?, in André Crochetière, Jean-Boulanger et Conrad Ouellon (eds), Actes du 
XVe Congrès International des Linguistes, Québec, Université Laval, 9-14 août 1992, Sainte-Foy, Presses de l'Université Laval: 43-46.

1993 Gengo zetsumetsu no kiki mokuzen ni semaru - wareware gengogakusha wa nani o nasubeki ka (Japanese translation of "The Language Extinction Catastrophe Just Ahead: Should Linguists Care?"), Gengo, 22(8): 12-17.

1993 Eskimo-Aleut Family, in Jacob Ernest (ed.), Encyclopedia of the North American Colonies, New York, Charles Scribner's Sons, vol. 3: 53-56.

1993 Athabaskan, in Jacob Ernest (ed.), Encyclopedia of the North American Colonies, New York, Charles Scribner's Sons, vol. 3: 51-53.

1993 Language Endangerment (published in Japanese), in Osahito Miyaoka (ed.), Gengo no Kiki, Sapporo, Hokkaido University: 249-263.

1993 The Earliest Recorded Alaskan Eskimo Word [kuxta 1732], Fairbanks, Alaska Native Language Center, typescript, 14 pages.

1994 Crossroads?: A Twentieth-Century History of Contacts across the Bering Strait, in W.W. Fitzhugh and V. Chaussonnet (eds), Anthropology of the North Pacific Rim, Washington, D.C., Smithsonian Institution: 365-379.

1994 Language Endangerment, in Osahito Miyaoka (ed.), Languages of the North Pacific Rim, Sapporo, Hokkaido University, Hokkaido University Publications in Linguistics, 7: 283-293.

1994 Sirenikski Y- and Proto-Eskimo *Ñ-, Acta Linguistica Hafniensia, 27(2): 323-341. 1994.

1995 Language Loss in Alaska, the United States, and the World, Frame of Reference (Alaska Humanities Forum), 6(1): 1, 3-5.

1995 Inuit Nunait - Nunangit Yuget, color wall map of Eskimo-Aleut world 36" x 64", Fairbanks, Alaska Native Language Center.

1996 The Russian Language in Alaska and in Alaska Native Languages, Atlas of Languages of Intercultural Communication, 2(1): 1209-1212.

1996 The Status of Native American Language Endangerment, in Gina Cantoni (ed.), Stabilizing Indigenous Languages, Flagstaff, Northern Arizona University, Center for Excellence in Education: 16-21.

1996 Linguistics and Biology: Threatened Linguistic and Biological Diversity Compared, CLS (Chicago Linguistic Society), 32: 69-75. 
1997 The Indigenous Languages of the North: A Report on their Present State, in H. Shoji and J. Janhunen (eds), Northern Minority Languages: Problems of survival, Osaka, National Museum of Ethnology, Senri Ethnological Studies, 44: 1-34.

1997 Foreword, in Knut Bergsland, Aleut Grammar, Fairbanks, Alaska Native Language Center.

1998 The Scope of the Language Endangerment Crisis and Recent Response to it, in K. Matsumura (ed.), Studies in Endangered Languages, Tokyo, Hituji Syobo, ICHEL Linguistic Studies, 1: 101-113.

1998 The Condition of Native North American Languages: the Need for Realistic Assessment and Action, International Journal of the Sociology of Language, 132: 9-21.

1998 Foreword, in Knut Bergsland, Ancient Aleut Personal Names, Fairbanks, Alaska Native Language Center: 7-9.

1999 Plains Apache Language Documentation, Fairbanks, Alaska Native Language Center, typescript, 15 pages.

2000 Koyukon Dialectology and its Relationships to other Athabaskan Languages, in Jules Jetté and Eliza Jones, Koyukon Athabaskan Dictionary, Fairbanks, Alaska Native Language Center: l-lxv.

2000 Some Traits of the Modern Orthography, in Jules Jetté and Eliza Jones, Koyukon Athabaskan Dictionary, Fairbanks, Alaska Native Language Center: lxxii-lxxiv.

2000 History and Future of Koyukon Language work, in Jules Jetté and Eliza Jones, Koyukon Athabaskan Dictionary, Fairbanks, Alaska Native Language Center: lxxv-lxxx.

2000 Koyukon Kinship, in Jules Jetté and Eliza Jones, Koyukon Athabaskan Dictionary, Fairbanks, Alaska Native Language Center: 815-822.

2000 Loanwords in Koyukon, in Jules Jetté and Eliza Jones, Koyukon Athabaskan Dictionary, Fairbanks, Alaska Native Language Center: 823-829.

2000 Bering 1728 and Gvozdev 1732, paper presented at Science under Sail: Russian Exploration in the North Pacific, 1728-1867, Anchorage, Cook Inlet Historical Society Symposium, typescript, 10 pages.

2000 Statement by Michael E. Krauss, Director Emeritus, Alaska Native Language. Center, University of Alaska Fairbanks, July 20, 2000, at Hearing on S.2688, the Native American Languages Act Amendments Act 
of 2000 (pdf version on line at: http://indian.senate.gov/2000hrgs/nala 0720/krauss.pdf).

2001 Mass Language Extinction, and Documentation: The Race against Time, in Osamu Sakiyama (ed.), Lectures on Endangered Languages: 2 - from Kyoto Conference 2000, Sapporo, Endangered Languages of the Pacific Rim, ELPR Publication Series C002: 19-39.

2001 Linguistic Arrogance and Endangered Languages, in Osamu Sakiyama (ed.), Lectures on Endangered Languages: 2 - from Kyoto Conference 2000, Sapporo, Endangered Languages of the Pacific Rim, ELPR Publication Series C002: 203-206.

2003 The Languages of the North Pacific Rim 1897-1997 and the Jesup Expedition, in Laurel Kendall and Igor Krupnik (eds), Constructing Cultures Then and Now: Celebrating Franz Boas and the Jesup Expedition, Washington, D.C., Arctic Studies Center, Contributions to Circumpolar Anthropology, 4: 211-21.

with E. A. DOBRIEVA, E. V. GOLOVKO and S. A. JACOBSON (compilers)

2004 Naukan Yupik Eskimo Dictionary, S. A. Jacobson (ed.), Fairbanks, Alaska Native Language Center, 421 pages.

2004 Introduction, in E. A. Dobrieva, E. V. Golovko, S. A. Jacobson and M. E. Krauss (compilers) Naukan Yupik Eskimo Dictionary, Fairbanks, S. A. Jacobson (ed.), Alaska Native Language Center: v-x.

2004 Bibliography, in E. A. Dobrieva, E. V. Golovko, S. A. Jacobson and M. E. Krauss (compilers), Naukan Yupik Eskimo Dictionary, Fairbanks, S. A. Jacobson (ed.), Alaska Native Language Center: xix-xxv.

2004 Placenames, in E. A. Dobrieva, E. V. Golovko, S. A. Jacobson and M. E. Krauss (compilers), Naukan Yupik Eskimo Dictionary, Fairbanks, S. A. Jacobson (ed.), Alaska Native Language Center: 371-421.

with E. V. GOLOVKO, E. A. DOBRIEVA and S. A. JACOBSON (compilers)

2004 Slovar' Iazyka Naukanskikh Eskimosov (Russian version of Naukan Yupik Eskimo Dictionary), translated by I. V. Krupnik and E. V. Golovko, Fairbanks, Alaska Native Language Center, 369 pages.

2004 Vvedenie, in E. V. Golovko, E.A. Dobrieva, S. A. Jacobson and M. E. Krauss (compilers), Slovar' Iazyka Naukanskikh Eskimosov, translated by I.V. Krupnik and E.V. Golovko, Fairbanks, Alaska Native Language Center: v-xiv.

2004 Bibliografiia, in E. V. Golovko, E. A. Dobrieva, S. A. Jacobson and M. E. Krauss (compilers), Slovar' Iazyka Naukanskikh Eskimosov, translated by 
I.V. Krupnik and E.V. Golovko, Fairbanks, Alaska Native Language Center: $x x v-x x x$.

2004 Nazvaniia mest, in E. V. Golovko, E. A. Dobrieva, S. A. Jacobson and M. E. Krauss (compilers), Slovar' Iazyka Naukanskikh Eskimosov, translated by I.V. Krupnik and E.V. Golovko, Fairbanks, Alaska Native Language Center: 319-369.

2004 Lexical Documentation of Endangered Languages, in Osamu Sakiyama, Fubito Endo, Honoré Watanabe and Fumiko Sasama (eds), Lectures on Endangered Languages: 4 - From Kyoto Conference 2001, Sapporo, Endangered Languages of the Pacific Rim, ELPR Publication Series C-004: 47-50.

with Luila MAFFI and Akira YAMAMOTO

2004 The World's Languages in Crisis: Questions, Challenges, and a Call for Action, in Osamu Sakiyama, Fubito Endo, Honoré Watanabe and Fumiko Sasama (eds), Lectures on Endangered Languages, 4 - From Kyoto Conference 2001, Sapporo, Endangered Languages of the Pacific Rim, ELPR Publication Series C-004: 23-28.

2005 Foreword, in John Enrico (ed.), Haida Dictionary, Fairbanks, Alaska Native Language Center and Sealaska Heritage Institute: vi-vii.

2005 Athabaskan Tone [1979 with additions], in Sharon Hargus and Keren Rice (eds), Athabaskan Prosody, Amsterdam and Philadelphia, John Benjamins, Current Issues in Linguistic Theory, 269: 51-136.

2005 Eskimo languages in Asia, 1791 on, and the Wrangel Island-Point Hope connection, Études/Inuit/Studies, 29(1-2): 163-185.

in press Status of Alaska Native Languages 1979-2000 and their Documentation, in Miyaoka, Osahito, Osamu Sakiyama and Michael Krauss (eds), Vanishing Languages of the Pacific Rim, Oxford, Oxford University Press (to appear in 2006).

in press Eskimo Language Work of A. S. Forshtein and Bogoraz, Fairbanks, Alaska Native Language Center, typescript (to appear in 2006). 